\title{
TIN MINING IN THE LIMESTONE CAVES OF PERLIS, MALAYSIA
}

\author{
RUDARJENJE KOSITRA V KRAŠKIH JAMAH PERLISA, \\ MALEZIJA
}

\author{
Liz PRICE ${ }^{1}$
}

\begin{abstract}
UDC 551.435.84:622.345(595)

Liz Price: Tin mining in the limestone caves of Perlis, Malay-

sia

Perlis is a small state in northern Malaysia, and it has both isolated tower karst hills as well as a long range of limestone hills. Many of the natural caves within this hill range contain alluvial tin deposits that were extensively mined during the $20^{\text {th }}$ century on a scale that is unique for tin ores from caves.

Keywords: Perlis, Peninsular Malaysia, tin, alluvial ore, mining, cave.
\end{abstract}

\begin{abstract}
Izvleček
UDK 551.435.84:622.345(595)

Liz Price: Rudarjenje kositra v kraških jamah Perlisa, Male-

$z i j a$

Perlis je majhna država na severu Malezije. Ima tako območja izoliranega stolpastega krasa, kot območja kopastega krasa, kjer v številnih kraških jamah najdemo aluvijalne sedimente, bogate s kositrom. Rudarjenje $\mathrm{v}$ teh jamah je potekalo $\mathrm{v} 20$. stoletju in je po obsegu presegalo primerljiva rudarjenja $\mathrm{v}$ kraških jamah.

Ključne besede: Perlis, polotoški del Malezije, kositer, ruda v aluviju, rudarjenje, jama.
\end{abstract}

\section{INTRODUCTION}

Perlis is the smallest state in Malaysia, and also the northernmost, situated in the northwest corner of the peninsula, with the border to Thailand wrapped round its northern margin. It has the southernmost limestone range on the mainland of Southeast Asia, the remainder of the limestone within Peninsular Malaysia occurs as isolated outcrops and towers. The Setul Boundary Range is riddled with caves, many of which have active streams that are rarely found elsewhere in the peninsula. This limestone range is unique because it is the longest such range in the peninsula, it is formed of the oldest limestone in the country and the natural caves have been mined extensively for the tin minerals within their alluvial sediments. Nowhere else in the world has tin been mined to such an extent from deep within limestone caves.
There are two groups of limestone hills within Perlis (Fig. 1). The Setul Hills form a continuous belt of mountainous country along the western border of the state (Fig. 1). They form steep polygonal karst, with fewer cliffs, more subdued slopes and more forest cover (Fig. 3). The highest peak of the Setul range is Bukit Pelarit at $553 \mathrm{~m}$. The Setul Hills contain the caves with the tin deposits, mainly in the area around Kaki Bikit.

In contrast, in a north-south belt through the centre of the state, the Chuping Hills are formed of eroded fragments of a strong, white, Permian limestone lying within the core of north-south synclines. They form a spectacular landscape that comprises a series of steep-sided hills and isolated towers rising from alluvial plains, and are clad in dense but stunted vegetation except on tall cliffs

${ }^{1}$ B-12-3, Le Chateau 2, Lorong Syed Putra Kiri, 50460 Kuala Lumpur, Malaysia, e-mail: lizprice@hotmail.com

Received/Prejeto: 14.10 .2010 


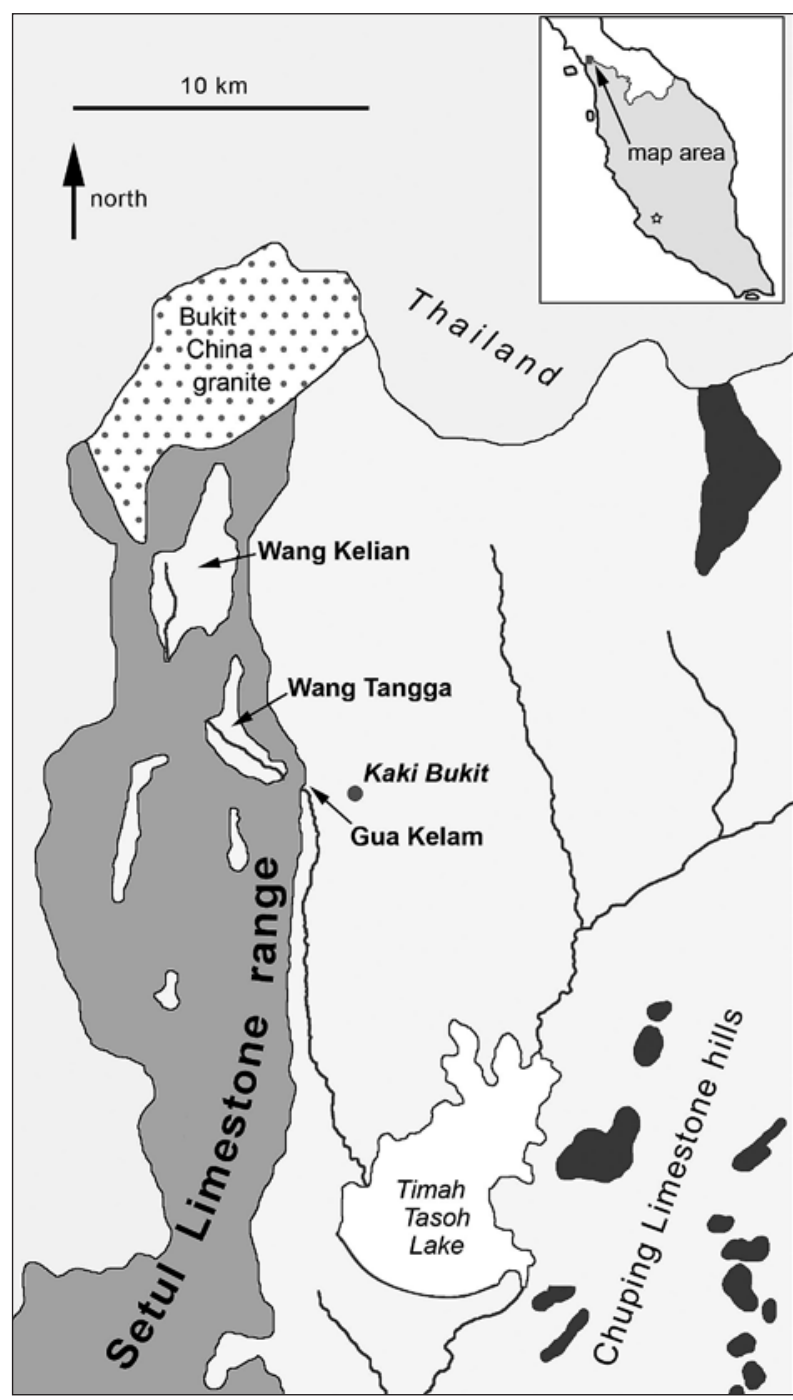

Fig. 1: Outline map of northern Perlis. Away from the limestones and the granite, most of the ground is underlain by sandstones and mudstones. Alluvium is extensive on these towards the south, and also floors the wangs within the Sentul Hills.

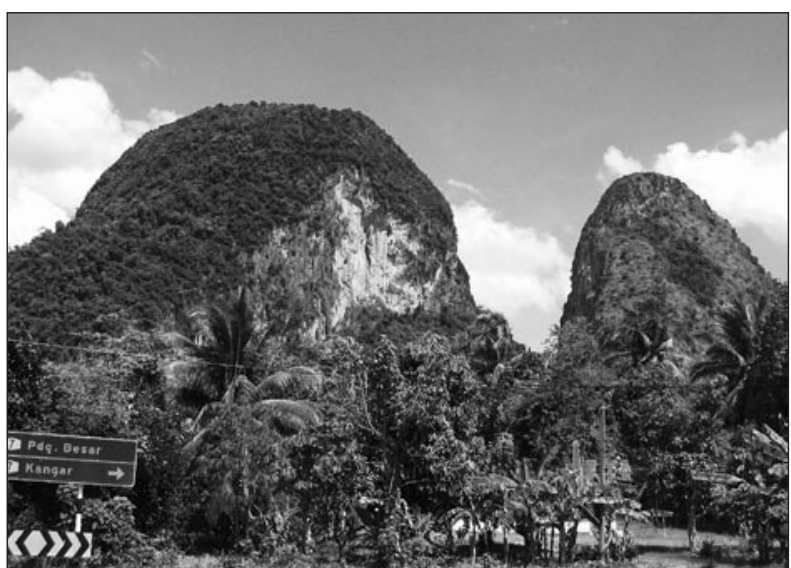

Fig. 2: Steep-sided hills of the Chuping Limestone (Photo: L. Price).

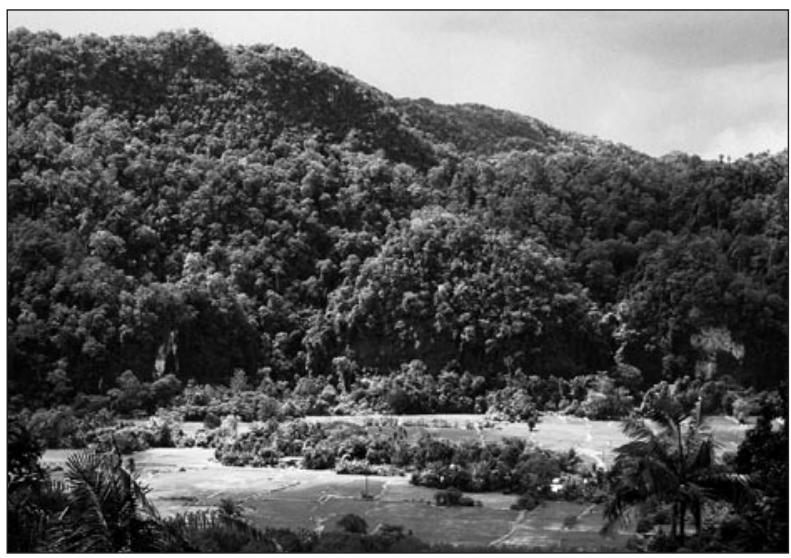

Fig. 3: Limestone hills of the Setul Range, with Wang Kelian in the foreground (Photo: T. Waltham).

of bare rock (Fig. 2). They contain a variety of cave passages and undercut foot caves.

Between the Setul and Chuping Hills, sandstones form hills rising north to the Thailand border, and are overlain by alluvial plains towards the south.

\section{GEOLOGY OF THE SETUL HILLS}

This long range of rugged hills is formed in an anticline of the dark, thick-bedded limestones of the Setul Formation, of Ordovician to Lower Devonian age. Limestone was not laid down continuously over this period, but was formed during distinct phases separated by intervals of non-deposition; it contains many argillaceous impurities and bands of mudstone, as well as chert and iron oxide. The sequence was folded in Mesozoic times, when it was also intruded by granite (Fig. 1). The Bukit China granite forms the highest land in northern Perlis, the tallest peaks being Bukit China at $724 \mathrm{~m}$ and Khao China which is across the border in Thailand and is $741 \mathrm{~m}$. This is the southern end of a granite body that extends northwards for more than $100 \mathrm{~km}$ into southern Thailand.

The granite has all the features of late-stage mineralisation in its marginal zones, with hydrothermal veins, pegmatites, aplite dykes and greisen. Tourmaline and topaz are common, as well as cassiterite (tin oxide), with relatively minor sulphides. Some of the contacts between the granite and the Setul Limestone are clean, with meta- 
morphic recrystallisation of the calcite to form marble. Other parts exhibit reaction between the limestone's carbonate and the granite's silica to create complex skarn deposit minerals. Lamprophyre dykes reach far into the limestone and are exposed in a quarry at Kaki Bukit and also in one wall of a cave passage in Gua Kelam 2.

Granite weathers rapidly in the tropical climate. Its feldspars and other silicate minerals break down to clays that are rapidly carried away by streams. The quartz and other resistant minerals produce coarse alluvial gravels that fill adjacent valleys and create wide floodplains. Within these alluvial gravels, the cassiterite and other heavy minerals are concentrated because of their greater density, forming lenses, strings and horizons of tin in quantities that are sufficiently rich as to have made mining of them economically attractive. The tin ores are found both in valley alluvium and in the caves (Fig. 4).

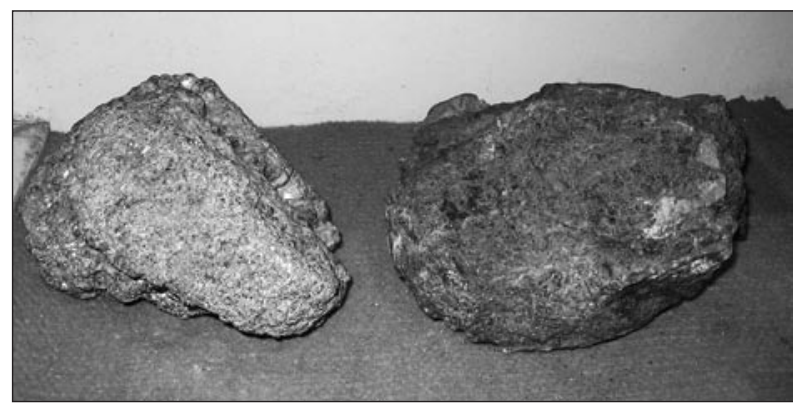

Fig. 4: Water-rounded alluvial cobbles of cassiterite (Photo: L. Price).

The alluvial tin on the surface occurs in the floors of deep valleys and depressions within the karst; these are generally surrounded by high cliffs or steep slopes, and are known locally as wangs, though not all have floors of alluvium. Wang Kelian is the first big depression south of the granite contact zone (Fig. 1). Wang Tangga is the next alluviated valley to the south. Wang Kelian has surprisingly little tin in its alluvium and has never been mined, but Wang Tangga has tin-bearing alluvium up to $15 \mathrm{~m}$ deep and has been extensively mined.

Tin-rich alluvium has been swept into the caves since the formation of the karst, and has proved to in- clude some of the richest ore. In most passages the cave alluvium is only a few metres thick, but it reaches much greater thicknesses in large chambers (Jones 1978). At some sites, notably where the current was checked at the foot of waterfalls, the heavy cassiterite is concentrated in lenses and pockets within the alluvium. One pocket in a cave at Wang $\mathrm{Mu}$, south of Kaki Bukit, contained 90\% cassiterite and in 1938 yielded tin worth more than a million Malayan dollars (at that time 60 Malayan dollars $=7$ British pounds). But tin values are very variable, with good ore typically carrying between $1 \%$ and $5 \%$ tin, and much of the alluvium was barren. Alluvial tin occurs in active stream caves, but most now lies in abandoned phreatic passages and chambers. Some of the alluvium is partially cemented by calcite, and in places it is capped by thick calcite flowstones that have been dated to approximate ages of $280-400 \mathrm{ka}$ (Smart et al. 1984). The

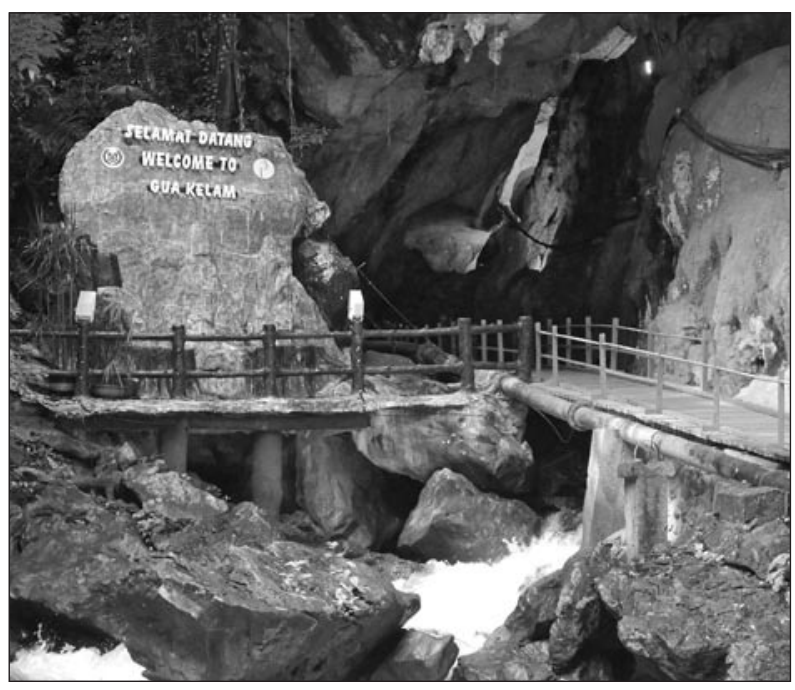

Fig. 5: The downstream entrance to Gua Kelam 1, with the miners' walkway that reaches through to Wang Tangga (Photo: L. Price).

main caves containing the tin lie between Wang Tangga and Kaki Bukit, some $6.5 \mathrm{~km}$ south of the granite (Fig. 5), and also in caves further south as far as the Alor Kangar mine, less than $8 \mathrm{~km}$ from Kaki Bukit.

\section{THE MINING INDUSTRY}

The centre of the tin mining industry was the small town of Kaki Bukit, on the eastern side of the limestone hills in northern Perlis; its name means 'at the foot of the hill'. Tin mining was an important industry in Perlis from the early 1900 s to the 1960 s. As it was relatively easy to extract the tin from the cave alluvium, many of the caves in the Setul range have been mined. 
Little is known of the early history of the tin mining industry in Perlis. Mining had definitely started by the first years of the $20^{\text {th }}$ century, but it is fairly certain that Chinese settlers began to exploit the deposits on a small scale well back in the $19^{\text {th }}$ century. Prior to the First World War, primitive methods were used to work the deposits, then European miners arrived in Perlis with more modern systems. This enhanced production figures and brought Perlis to prominence as a tin-producing state. However, mining the alluvium from deep within the caves was difficult and arduous work, and the production of tin ore from Perlis only amounted to $0.7 \%$ of the total recovered in Malaya, which at one time was one of the world's main producers of tin.

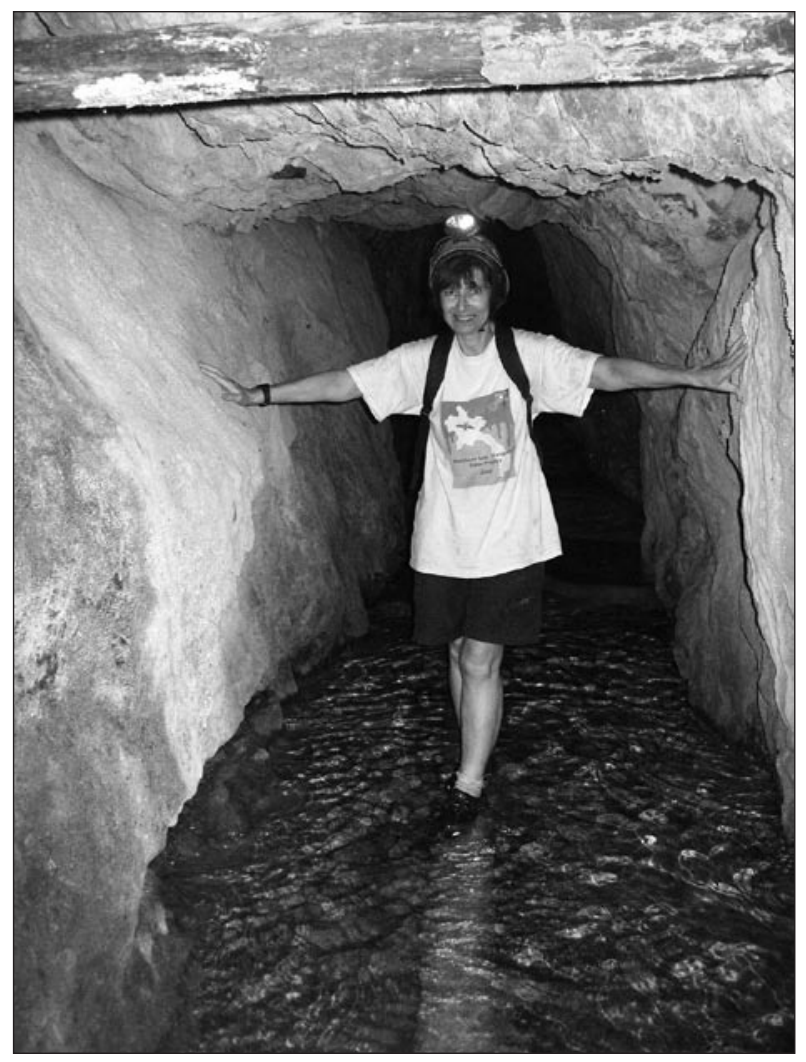

Fig. 6: The artificial tunnel driven into a mine beside Wang Mengkuang (Photo: L. Price).

Records of the mining are known from 1909, but detailed records were only kept after 1952 when the mines came under the jurisdiction of the Federation Department of Mines. After the Second World War, Malaya was occupied by the Japanese, during which time the mining industry was virtually dormant, and also many records were lost. The main mines were located within a radius of $4 \mathrm{~km}$ of Kaki Bukit. In 1953-1961, there was an average of 25 mines working, of which all were in caves except for two surface workings. Some were small operations, with perhaps around five labourers, while others were huge fully equipped mines. Where possible, the tin miners just followed the natural cave passages, but they also drove access tunnels into some of the caves (Fig. 6).

The mining methods were fairly straightforward, as the tin-bearing alluvium is generally free of, or only loosely consolidated by calcite. Some mines, especially those where the alluvium was cemented by calcite, used simple methods where the ore was dug with picks and shovels and taken out by trolley. Out in daylight, the ore was crushed and then separated by dulang washers hand washing using large gently-dished wooden pans to wash the light quartz sand away from the granular cassiterite (Fig. 7).

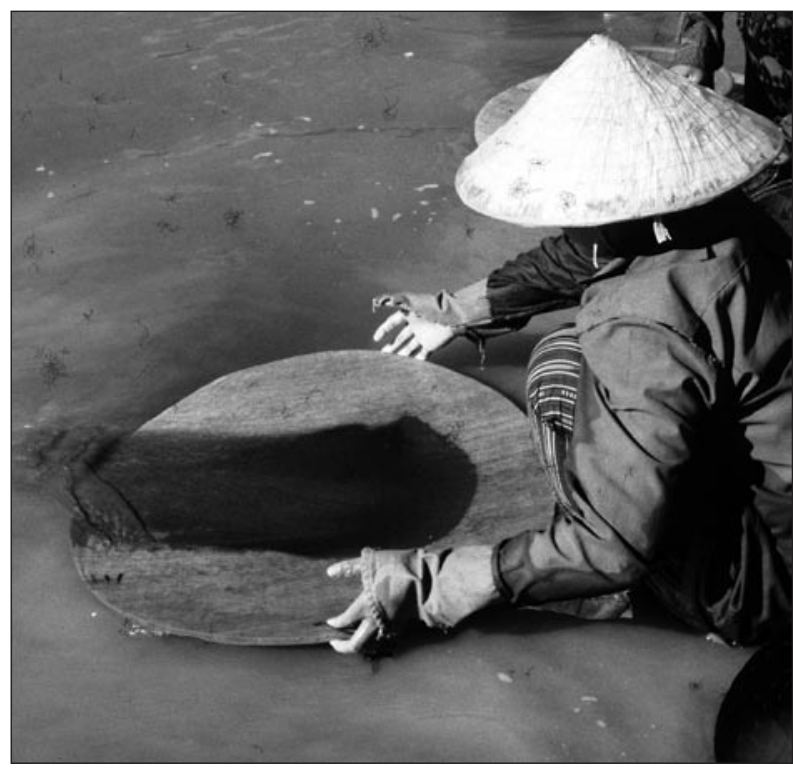

Fig. 7: Dulang washers improving the grade of fine-grained alluvial cassiterite; these are working at a tin mine in Laos, which is also in a sedimentary basin within a karst terrain (Photo: T. Waltham).

In other mines, high pressure water hoses, known as monitor pumps, were used to wash out the alluvium as a mobile slurry. The pumps were supplied with water pumped in from outside and fed through pipes to the working face. Water storage tanks were also built in some of the caves. In Gua Baba, the upper part of the cave system was dammed to provide a high level water supply with the necessary pressure to operate the monitors. Separation of the tin ore took place either in the mine or where the washings were pumped out to daylight for processing. Both underground and on the surface, the tin ore was mainly separated in conventional wooden sluices, locally known as palongs; these had riffle bars to collect the heavy ore mineral as the alluvium was washed 
down the sluices' sloping box channels. Some of the larger mines were fitted with modern machinery thousands of metres inside the hills, and employed gangs of a hundred or more labourers within the caves and mined tunnels.

Where the natural cave passages were small, they were enlarged by blasting. In many places, the caves contained large chambers, and the tin-bearing alluvial deposit could be more than $10 \mathrm{~m}$ thick. Some cave passages filled with tin-rich sediment extended to depths of a few hundred metres, and were completely mined out. One of the longest mined caves recorded in 1978 reached a length of about 2,000 m. Some caves were dry. Others contained streams, and flash floods occurred during the rainy season, when some sections of the mines were closed for fear of flooding. The unpredictable flash floods, falling rocks and collapsing wooden walkways were just some of the perils the miners faced in the caves.
Surface operations were also concentrated on the Kaki Bukit area, working the alluvium in the open wangs. Gravel pump mines excavate a pond in the alluvium and then pump the gravel slurry from its floor. Hydraulic mines use monitor jets to wash the alluvium from exposed faces. The alluvium in Wang Tangga was profitably worked before World War II, but the ore was exhausted by 1961 and all surface production ceased.

Most of the caves were almost mined to exhaustion by the 1960s after the average labour force had peaked at around 2,500 people. World tin prices plummeted in the 1980s, and sealed the fate of the surviving mines. Today a few individual miners still live in the Kaki Bukit area, and some go into the caves to search for any easily available tin.

\section{THE CAVES NEAR KAKI BUKIT}

Numerous cave entrances and resurgences fringe the valley floors at the base of the limestone range, but entrances are also located high up in the hills. According to the miners, many of these cave systems are connected. Many of the caves still contain mining relics. Several still have the rail tracks for the trolleys, some have wooden walkways suspended by wire cables, and Gua Kelam 2 has an engine room with huge diesel generators. Some of the caves are home to a variety of cave fauna, such as bats, large toads, fish, crabs, and invertebrates such as centipedes, crickets, millipedes and spiders (Fig. 8). Some of the major caves are listed below.

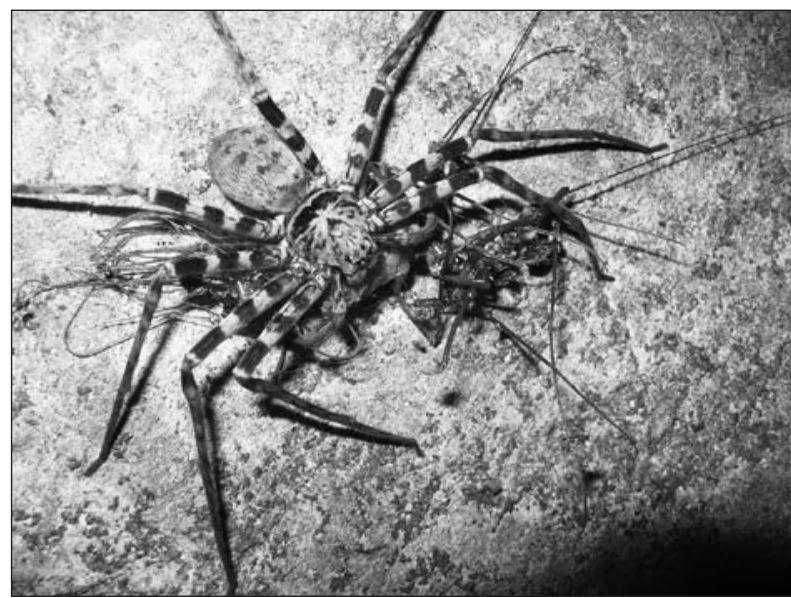

Fig. 8: A huntsman spider eating a long-legged centipede, in the small Kaki Bukit Temple Cave (Photo: L. Price).
Gua Kelam 1 is a natural cave that gives access through the hill from Kaki Bukit into Wang Tangga (Fig. 9). In 1935, an English miner had a 370 m wooden suspended walkway built above the stream through the entire length of the cave (Fig. 10). This allowed the miners to transport tin ore out from Wang Tangga without wading in the cave stream and to pass cascades of flowstone from high-level inlets that almost block the stream passage (Fig. 11). Today the cave is set up as a tourist cave. It is electrically lit with multi-coloured lights, there are information boards. A small entrance fee is charged.

Gua Kelam 2 is 3,748 $\mathrm{m}$ long and has four entrances (Fig. 9). The hard calcite-cemented alluvium was dug by pick and shovel and transported from the mine in rail trolleys. The material was crushed by mechanical foot stamps and the ore separated by dulang washing. By 1957 the main cave had been worked for a distance of about $610 \mathrm{~m}$, and was cleared of tin-bearing alluvium to a depth of $110 \mathrm{~m}$. Today Gua Kelam 2 is used as a show cave and for adventure caving. Visitors enter on a trolley train, then walk along a concrete walkway for about an hour, passing artefacts that include as old water pipes and mining tools (Fig. 12), and also wooden bridges across the cave lakes. Part of the cave floor has been polished by the stream action to reveal white and black banding in the impure limestone sequence. The exit is from a high level passage in the other side of the hill, below which lies a streamway entrance (Price 1993). 


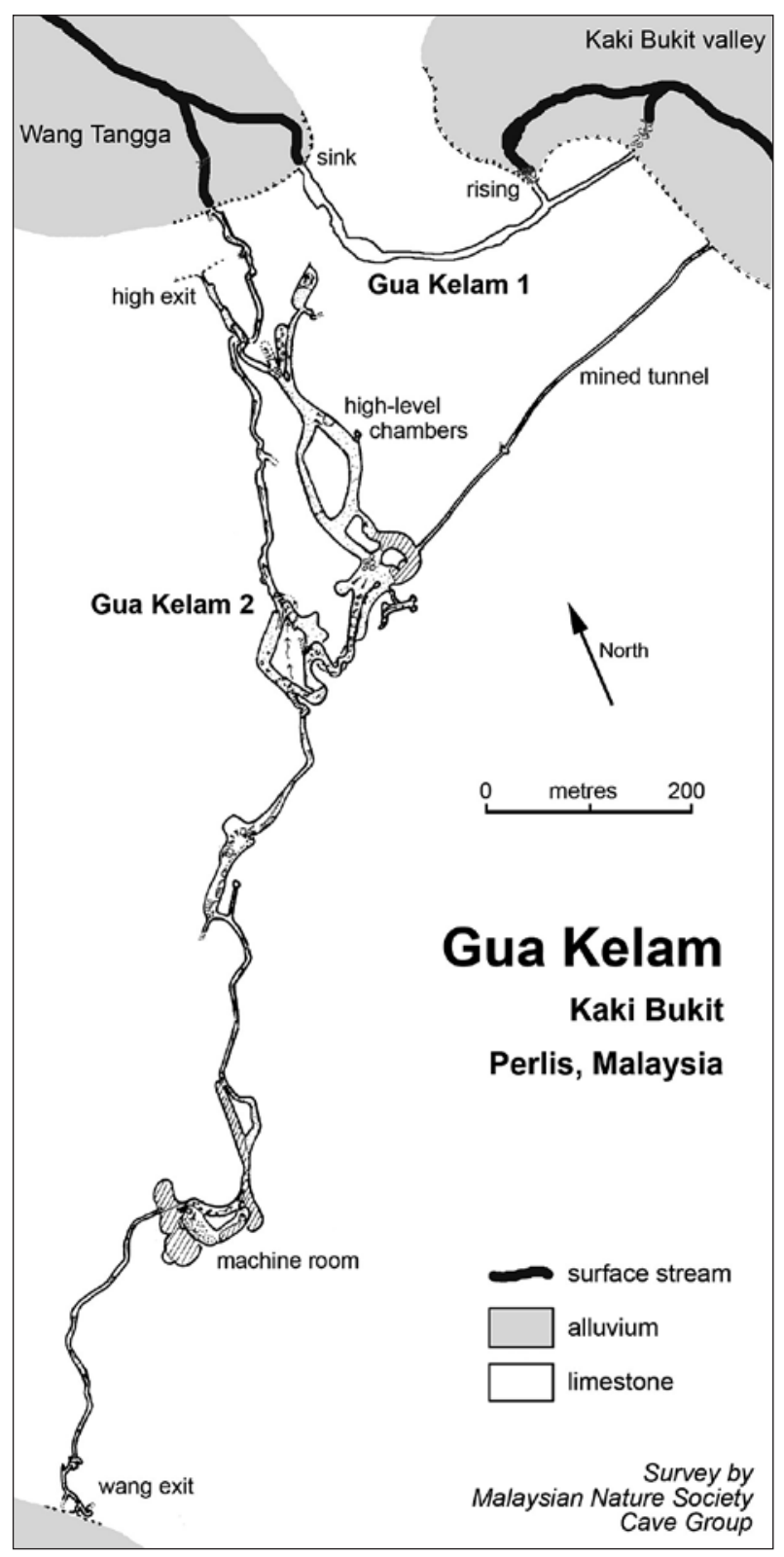

Fig. 9: Survey of Gua Kelam (by the Malaysian Nature Society Cave Group; redrawn by T. Waltham).

Gua Baba is a resurgence cave south of Kaki Bukit, and was mined from the 1940s until 1958 (except during the period of the Japanese occupation) as the Khai Fatt Tin Mine (Jones 1978). A narrow stream passage continues upstream through five large chambers. The fourth chamber contained alluvium $10 \mathrm{~m}$ deep that was famously rich in tin, and yielded more than 10 tonnes of tin per month through 1955. A diesel engine pumped water to hydraulic monitors at the work face, and gravel pumps, water pumps and a palong sluice were constructed underground, with dulang washing sheds built outside the entrance. The miners' wooden walkways are still in place,

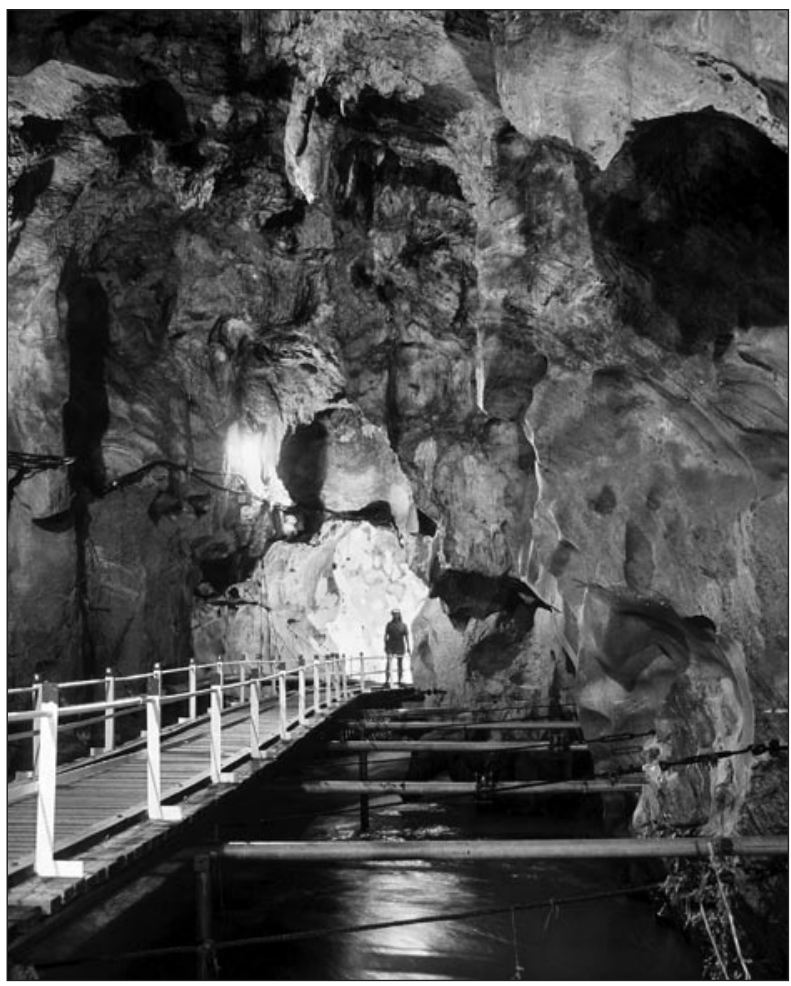

Fig. 10: The miners' walkway over the stream through Gua Kelam 1 (Photo: T. Waltham).

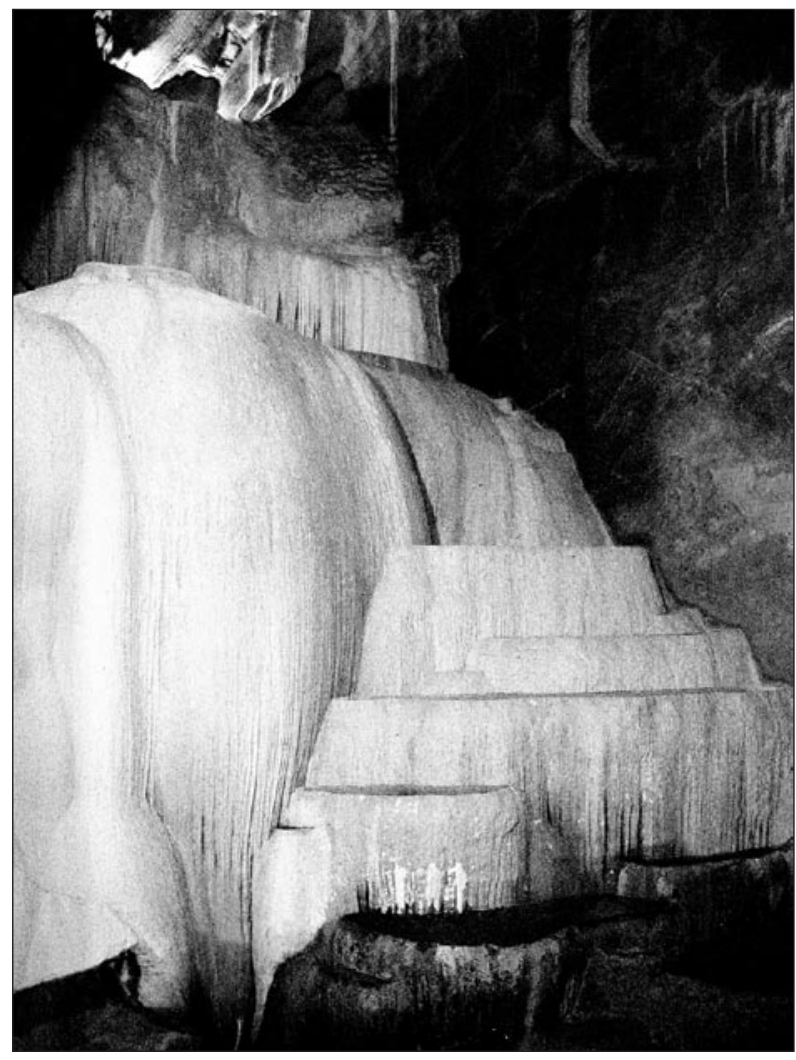

Fig. 11: A large bank of flowstone in the Gua Kelam 1 stream passage (Photo: L. Price). 


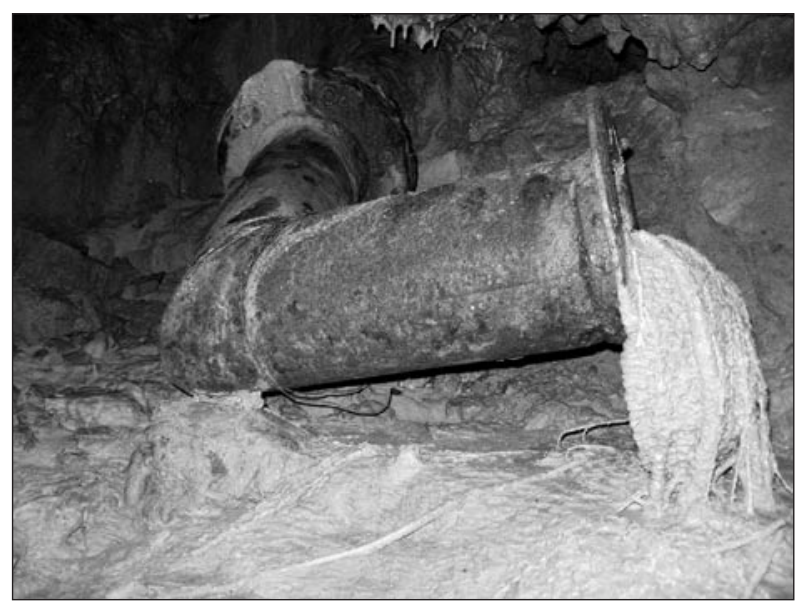

Fig. 12: An old monitor pipeline with calcite precipitated by seepage water, in Gua Kelam 2 (Photo: L. Price). although many are now submerged by water. By 1957 the mining had worked into the cave for a distance of $610 \mathrm{~m}$. The passages are now known to connect to Lo Po Sang which has an entrance high up on the hill, in a system that is around 2,400 $\mathrm{m}$ long.

Gua Wang $\mathrm{Mu}$ is another resurgence cave containing some large chambers. The Foh Thye Mine has an entrance up on the hill above Wang Mu (Price 2000). It worked gravels from natural cave passages that descend through some large chamber and small streamways, and has been surveyed to a length of 2,100 $\mathrm{m}$.

\section{ACKNOWLEDGEMENTS}

The author thanks Tony Waltham for assistance in preparing this paper and its maps.

\section{REFERENCES}

Jones, C.R., 1978: The geology and mineral resources of Perlis, North Kedah and the Langkawi Islands.- Geological Survey of Malaya, District Memoir 17, pp. 257, Kuala Lumpur.

Price, L., 1993: Gua Kelam 2.- International Caver, 7, 11-18.
Price, L., 2000: Perlis 96 and 98.- International Caver, 32-37.

Smart, P.L., Andrews, J.N. \& B. Batchelor, 1984: Implications of Uranium series dates from speleothems for the age of landforms in north-west Perlis, Malaysia: a preliminary study.- Malaysian Journal of Tropical Geography, 9, 59-68. 